\title{
Coronavirus Apocalypse: A Representation of Despair and Resilience
}

\author{
Nesreen Al-Harby \\ Department of European Languages and Literature \\ Faculty of Arts and Humanities \\ King Abdulaziz University \\ Jeddah, Saudi Arabia \\ Email: naalharby@kau.edu.sa
}

Received: 6/29/2021

Accepted: 8/2/2021

Published: $8 / 25 / 2021$

\begin{abstract}
:
This paper explores Mathias Besong's My Struggle with COVID-19 (2020), Nikita Gill's Love in the Time of Coronavirus (2020), and Elizabeth Mitchell's The Doctor and Apocalypse (2020) and focusses on how these poems illustrate authors' reactions to the spread of coronavirus. Therefore, it engages genre theory and argues that the examined verse adopts features and themes of postapocalyptic literature. The research employs a comparative approach that divides the poems into three categories: the poetry of despair, the poetry of hope, and the ambivalent poetry that depicts responses to the pandemic inconsistently. The study shows that the explored poems express contradictions between social distancing, physical isolation, and global connectedness and oneness. This paper scrutinizes the concept of survival and examines features of coronavirus survivors as significant elements in the explored genre. The research debates that human reactions to distress are universal. It also draws attention to the effectiveness of writing poetry to aspire to hope, achieve global human solidarity, and challenge fear and hardships. The research demonstrates the social impacts of Covid-19 and how poetry becomes a means that expresses fear and hope through its employment of post-apocalyptic conventions and tropes. Finally, the researcher suggests that the examined poets depict their anxieties and psychological distress; however, they overlook illustrating the physical pain associated with coronavirus. This study contributes to ongoing scholarly discussions that focus on selected poems produced during the Covid-19 context and sheds light on their genre, conventions, and tropes.
\end{abstract}

Keywords: coronavirus poetry, curfew, post-apocalyptic literature, lockdown, social distancing, Covid-19 social changes, social media literature

Cite as: Al-Harby, N. (2021). Coronavirus Apocalypse: A Representation of Despair and Resilience. Arab World English Journal for Translation \& Literary Studies 5 (3) 55.-69. DOI: http://dx.doi.org/10.24093/awejtls/vol5no3.5 


\section{Introduction}

During the first quarter of 2020, the world encountered a severe outburst of Covid 19, a fatal virus that attacks human bodies. Shereen, Khan, Kazmi, Bashir, and Siddique (2020) confirm that the virus "was named as a coronavirus" because it has "crown-like spikes on the outer surface" and that before its outbreak, people thought they "infect only animals" (p. 92). However, "observations indicated a human to the human spreading capability of this virus, which was reported in more than 100 countries in the world" (p. 92). The spread of the disease resulted in a total or partial curfew and closing borders between countries, which affected worldwide human interaction. Physical interaction became highly restricted to avoid the dangers of the widely and rapidly spreading virus. This situation made virtual communication a new mode of many social and professional activities. Rodríguez-Rey, Garrido-Hernansaiz, and Collado (2020) confirm that due to the spread of coronavirus, "family dynamics have remarkably changed, travel is restricted, and there has been a reduction in leisure activities and social life" (p. 2). Schools, shopping malls, cinemas, workplaces, and markets, were shut down all over the globe, which affected the world's economy. International society and associations were alarmed by the consequent unemployment that affected people. Galofaro (2021) highlighted that the "economic crisis" that took place in the world after 2020 could be considered a direct result of the pandemic (p. 128). Rodríguez-Rey et al. emphasize that "many people have temporary or permanently lost their jobs, many are working from home, sometimes with insufficient preparation for doing so" (p. 2). Countries worked hard to provide for the affected and the unfortunate during this catastrophe. In a World Health Organization report, Chriscaden (2020) announces that the "COVID-19 pandemic has led to a dramatic loss of human life worldwide and presents an unprecedented challenge to public health, food systems and the world of work" and that "tens of millions of people are at risk of falling into extreme poverty" (p. 1). Hence, the WHO's report (2020) calls for "global solidarity and support" and advises countries "to develop long-term sustainable strategies" to tackle the physical and psychological difficulties that global societies face.

The distressed global society expressed its shock and fear during the spread of coronavirus in many ways. The universal aftermath of coronavirus - the rising mortality rates and the anxious struggle to survive - made the world view this deadly virus as terrifying as wars and natural disasters. It additionally created wide-reaching germophobic paranoid tendencies. Many drew upon previous human experiences with pandemics by comparing Covid 19 to cholera, plague, and Spanish flue. Academics and readers have been motivated to revisit historical texts to examine conceptions of humans' suffering caused by similar conditions of hardships. Poets and writers from diverse educational and literary backgrounds have participated in creating a global body of literature that illustrates countless social reactions to prevailing horrors. Campo and New (2021) clarify that many people "felt drawn to the alchemy of language as a way to make sense of what's happening in our medical centers, our communities, and the world" during the attack of Covid-19 (p. 12).

Concerns about humans' isolation under the quarantine and social distancing, the dread of losing loved ones, the fear of being infected, and the struggle to maintain emotional stability became trendy topics of poems and different forms of writings. Campo and New additionally confirm that during this traumatizing setting, many texts register "the loss, suffering, and resilience 
brought about by the coronavirus disease" (p. 12). Many poets and authors expressed their longing for the past before coronavirus. Others exhibited skepticism about the probable threats and dangers of the future. Nicewaner (2020) contends that "Psychological research suggests that experiencing times of crisis can trigger feelings of nostalgia" (p. 7). Additionally, Nicewaner (2020) emphasizes that nostalgia may become "a coping mechanism to combat loneliness" because it can be "beneficial to our mental health," and it provides people with a "greater sense of self and continuity" during bad times of crisis (p. 8). Hence, writing poetry, drama, and fiction works as a cultural activity that provides solidarity and connectedness. Simultaneously, it serves as a healing process through which writers and readers seek psychological and emotional comfort and relief. These texts question the validity of human survival and the soundness of people's security. Many inquire into the transformation of life to new, and probably irreversible, forms during what the author labels' Covid-19 context'. Part of these writings expresses human's perception of this historical and social context as either the end of the world or that it is the end of human life as people have always known it. In this light, unique social, historical, and cultural features shape literary works produced during the 'Covid-19 context'. Moreover, numerous texts written during this era relate to post-apocalyptic literature, its themes, and conventions.

This research argues that examined poems produced during the Covid-19 context often employ themes and conventions of apocalyptic and post-apocalyptic literature. Additionally, the author debates that coronavirus literature studied in this research expresses a juxtaposition of social distancing and isolation and simultaneous global connectedness and oneness. The researcher also suggests that poets and writers examined in this research depict their fears and psychological distress; however, they overlook physical pain during illustrations of the effects of coronavirus. Furthermore, this study claims that some of the examined texts show that literature can become a means of communication and adaptation during catastrophes, facilitating dealing with hardships and catastrophes. Finally, this paper scrutinizes the concept of survival by emphasizing the contradictory representation of survivors after the coronavirus attack. Hence, this work declares that despite their survival during this life-changing historical era, some become victims of the aftermath of the catastrophe while others become warriors who participate in saving the world. This paper questions similarities between a coronavirus context and a post-apocalyptic setting. It investigates the narrators' reactions to the spread of the pandemic and how that associates them with characters in post-apocalyptic literature. The research additionally inspects the texts' depictions of the reasons behind the catastrophe. Despite the long history and popularity of postapocalyptic literature, the connection between the genre features and coronavirus social and cultural contexts remains novel, and its exploration is timely. This research paper aims to contribute to the ongoing scholarly discussions of literary texts produced under the effect of the Covid-19 context and to underline the similarity between their features and those of postapocalyptic narratives.

\section{Literature Review \\ Genre Theory: Post-Apocalyptic Literature}

To situate post-apocalyptic literature within genre writing, it is vital to acknowledge the definitions and literary conventions of the genre. Theorists provided several definitions of postapocalyptic literature. Oventile (2002) has revealed that the word "apocalypse" is originally the 
"Greek word 'apokalypsis"' (p. 103), and it additionally signifies revelation of truth and a clear distinction between "good" and "evil" (p. 104). He has underlined that, as a genre, post-apocalyptic literature - "After the End" - relates to American postmodernism and "compulsively formats its political, novelistic, filmic, and pop-cultural narrations" through its apocalyptic settings and events (p. 104). Hicks (2016) defined post-apocalyptic literature as "material that depicts what might be called 'globalized ruin" (p. 7). Hicks (2016) has also explained that the depicted disaster is usually "of at least a national level and, by nature of our globalized political economy, assume dramatic effects elsewhere as well" (p. 7). Houfková (2019) has defined post-apocalyptic literature as "a specific sub-genre which depicts earth's civilization as collapsing or collapsed. The fictional postapocalyptic worlds reflect possible dangers and threats related to contemporary politics, environmental changes, culture, technologies, or society" (p. 59). Hill (2018) has confirmed that post-apocalyptic literary plot "takes place during or after an apocalyptic event such as a nuclear holocaust, a species-ending plague, a zombie outbreak, or an environmental collapse" ( $\mathrm{p}$ 1). Clasen (2019) describes the setting of post-apocalyptic literature as "the aftermath of a global or nearglobal disaster" (p. 65). He has added that the exposure to this kind of "fictional disasters" can "help us cope with anxieties about real possible disasters such as nuclear holocaust, epidemic disease, and environmental upheaval" (p. 66). Nyström (2021) has added that a "post-apocalyptic wasteland" becomes the "pastoral settings" where people can become in direct contact with hidden pure nature which contradicts with the "ruined world" or the spoiled universe before the fall of the catastrophe (p. 1).

Temporality in post-apocalyptic literature is vague, ambiguous, and inconsistent. This obscurity is illustrated by depicting incidents and catastrophes that have already occurred, might not have ended, and/or influence the present and future. Cohen and Pielak (2016) have confirmed that apocalyptic literature indicates, directly or indirectly, the end of the world, and they emphasize that "the frightening shadow of threatening apocalypse" can "focus our attention on both past and present" (p. 242). Dillon (2007) has revealed that the "narrative structure" of this genre indicates two temporal settings: time "before" and time "after" the tragedy (p. 376). This ideology of time sheds light on Derrida's distinguishing between what humans "are" before the catastrophe and what they "may become" (cited in Cohen \& Pielak, 2016, p. 242). Additionally, Cohen and Pielak have confirmed that an apocalyptic narrative "takes shape as revelation" where humans narrate and behold "transformation from present circumstances to some generally tragic future, exposing social fears that bring about tragic outcomes" (p. 242). Hence, they have indicated that postapocalyptic literature portrays a clear borderline between the present and the future, juxtaposing fearful and ambiguous future. The terrifying present is narrated through "the testimony of survivors" and is preserved through their illustrations (p. 246). This provides readers of the genre with a narrative that "gives voice to the silent gulf exists between what was and what is and what may be" (p. 248). Watkins (2020) has underlined that a post-apocalyptic plot commonly "generates a backwards-looking narrative stance" that "has an interpretive, explanatory function" (p. 9). Snyder (2011) has added that readers of post-apocalyptic literature "must sustain a kind of double consciousness with respect both to the fictionality of the world portrayed to its potential as our own world's future" (p. 470). Hence, despite engaging imagination as a central component of the genre, post-apocalyptic literature is still connected to realism through what may occur in the "futurist dystopia" (p. 471). 
Critics underline the psychological effects and the ethical impact of post-apocalyptic literature on readers. It engages readers in protagonists' involvement in the "pre- and post-" contexts of the apocalypse (Snyder, 2011, p. 471). Lepore (2020) suggested that in post-apocalyptic literature, dystopia becomes actual reality after being a fearfully "imagined future" or a previously dreaded space (p. 1). Characters and readers are lost in time and suffer between memories and anticipations of a better future. Watkins (2020) has argued that "human carelessness" and "excess technoscience and capitalist exploitation of natural resources" are commonly portrayed as reasons behind the depicted catastrophe in the genre (p. 10). Carroll (2006) has debated that post-apocalyptic literature can "provide paradigmatic and emotionally saturated images of the world and of human experience" and that this enhances people's comprehension of emotions and feelings (p. 42-43). Clasen (2019) underlined that "the fragility of western civilization" and the cruel wars that took place during the $20^{\text {th }}$ century "proved a particularly fertile period for post-apocalyptic fiction" (p. 6). Hence, he has emphasized that the genre serves to illustrate "warnings against the consequences of human folly" (p. 4). Manis (2019) has highlighted that the sociopolitical milieus during the $21^{\text {st }}$ century - such as the Post-9/11 context and the prevailing violence - affected the genre. Therefore, post-apocalyptic literature expresses "mythologizing and retelling national trauma and fear" (p. 1237). Considering this, Clasen (2019) has indicated that post-apocalyptic literature reveals to readers "that radical change-for the worse or in some cases the better-is always possible" (p. 4). As a result, it teaches readers what Ketterer (1971) calls "adaptability and elasticity of mind in the face of change" (p. 25). This type of writings exposes its reader to what Clasen (2019) has called "counterfactual cognition" and "imaginative culture" that can contradict with other genres, such as "social realism" (p. 4). This is due to two factors: the first is that post-apocalyptic literature describes rare and terrifying events as very likely to occur. The second is that the genre commonly illustrates total "global destruction" and other kinds of universal catastrophes (p. 4). Epstude and Peetz (2012) have clarified that expectations and fear of an impending catastrophe cause readers to dwell between the narrated past and the dread of the future, which abolishes conceptualization of the present and causes a forceful "emotional" dilemma (p. 269). Heller (2015) has drawn attention to the fact that "The world feels more precariously perched on the lip of the abyss than ever, and that facing those fears through fiction helps us deal with it." (p. 11). However, Galofaro (2021) has argued that the apocalyptic context provides "an opportunity for a moral change" (p. 127). Hence, post-apocalyptic literature, as much as it unfolds skepticism from the modern world and anxiety about dealing with postmodern social and economic features of life, reveals to readers the importance of adaptation to new modes in modern capitalist societies.

Perception of survival is ambivalent in post-apocalyptic narratives. Human survivors suffer during the disaster due to feelings of loss, despair, and powerlessness. Hill (2018) has emphasized that a post-apocalyptic narrative "is a story that takes place after a revelation of some kind. Following a small group of survivors as they try to retain their pre-apocalyptic identities." Hence, "the post-apocalyptic novel reveals important truths about humanity to both the characters within the narrative and the reader" (p. 125). Morton (2013) has emphasized that one of the challenges after a massive catastrophe is the conflict between despair and the urge to reconstruct the world. Stifjell (2018) has emphasized that human survivors wonder during and after the apocalypse: "if the world is already ending, then what is the point in taking action or preparing for the future?" (p. 15). Post-apocalyptic literature highlight humans' negative impact on the environment and the 
world as a whole due to industrialization and human's perceptions of superiority over other species and nature. Stifjell (2018) has highlighted that apocalyptic literature describes rising levels of environmental contamination, erosion of forest and rising "sea levels and temperatures," which indicates "the end of the world" and an "environmental crisis that threatens the future liveability of the planet" (p. 14). According to Tsing, Bubandt, Gan, and Swanson (2017), survivors of any environmental apocalypse should retreat and learn how to "limit the destruction" of the world we live in and learn new strategies to guard the environment for mankind to be able to live safely on the planet again (p. 2). Manis (2019) has also underlined that "survival depends on an ability to adapt to new ethical paradigms" (p. 1243). Hence, Stifjell (2018) has announced that postapocalyptic literature draws attention to the dangers of underestimating the significance of ecological balance and jeopardizing the relationships between humans and non-humans and nature. She has further highlighted that the genre warns against Western Othering of the non-white in different geographical spaces. Accordingly, genre theory indicates that the destruction of the universe and the annihilation of its inhabitants are the results of two factors. The first is the natural physical consumption of the planet by humans. The second is the unethical abuse of the nonWestern Other. Both factors illustrate that post-apocalyptic literature necessitates and urges humankind to repent and rectify immoral practices if they desire to construct a new universe and live again in peace among themselves and with non-human beings.

\section{Textual Analysis}

In the post-Covid-19 context, many people articulated their confusion and fear through poetry writing. They described their hardship and anxiety and sought relief through connecting with others at a universal level. Like poems examined in this research, a massive body of literature appeared on the internet and social media platforms - like Facebook and Twitter - to share writers' feelings of shock and despair in reaction to the coronavirus attack. Bloggers utilized cyberspace to create a global collective view to make sense of what was happening in the world. GonzálezPadilla and Tortolero-Blanco emphasize (2020) that "Social media platforms have also become helpful for the lay public to maintain communication" (p. 120). They explain that social media activities "reduce isolation and boredom which have been associated with anxiety and long-term distress, therefore becoming an important recommendation for isolation at home to help to reduce the psychological impact" (p. 120). Therefore, the lockdown has motivated many poets to explore themes and topics that express agony due to lockdown, isolation, alienation, and social distancing. Additionally, it became a vehicle through which many people expressed their perception of the outcomes of coronavirus.

Other writings focussed on the positive side of the catastrophe. Their writings depicted their appreciation of human solidarity and social bonding during the lockdown. Therefore, they demonstrated their sense of hope, resilience, and adaptation to life as it is, trying to find a positive side of terrifying situations. Peters (2021) underlines that "individuals can learn techniques to build resilience" that can help them "cope or adapt when confronted with adverse life events" (p. 756). According to Peters (2021), this helps individuals develop "cognitive reframing techniques, character-building, stress management, viewing crises as challenges; learning to accept things you can't change; sharing feelings, and keeping things in perspective" (p. 756). Thus, individuals can become capable of improving their "social vulnerability" (p. 756). 
Another type of writings celebrated the revival of nature after the noticeable drop in levels of pollution. A National History Museum website article (2020) illustrates that "lockdown has given us a special glimpse at a world that once was: quieter, cleaner, more obviously full of nature" (p. 1). The article draws attention to many other factors that relate to air pollution:

Fewer cars, trains and buses on the roads meant one obvious environmental effect: an instant alleviation of air pollution. The sky-high observatory on top of the iconic BT tower in central London found that carbon dioxide emissions dropped by $60 \%$ during lockdown (p. 5).

In some countries, people saw the blue sky for the first time in decades after being concealed by thick grey clouds of smoke. Many industrial activities stopped. Curfews in many cities put an end to limitless poisonous gases spreading from car exhausts. Noise levels decreased noticeably, transforming earth into a more peaceful and quieter planet. The same article confirms that the "'hum' of daily life quietened dramatically during lockdown" and that "sensors across the country" marked" up to a 50\% drop in vibrations" (p. 10). The article explains that vibrations is "another word for sound" (p. 10). Further, writers focussed on animals roaming freely and leisurely and feeling secure due to man's absence during the Covid-19 lockdown. For example, dolphins and whales started to roam freely near coasts in many countries due to significantly reduced ship traffic ("Nature: liberated by lockdown?"). Hence, observing the world bloom after limiting human activities has motivated many writers to depict an emerging heaven-like world that frequently follows an apocalypse and comes after eliminating evil from the new world.

\section{Discussion}

Poems examined in this research can be divided into three categories: poetry that represents coronavirus as a time of death and destruction, poetry that illustrates Covid-19 context as a period of revival and solidarity, and poetry that is ambivalent in its representation of despair and resilience. Besong's (2020) My Struggle with COVID-19 is a poem written by a Nigerian epidemiologist and posted on Training Programs and Public Health Interventions Network (TEPHINET) in Lagos, Nigeria. The poem's title provides a realistic account of the doctor's personal experience who undergoes the tragedy of witnessing severe cases of death due to coronavirus. In addition, the poem depicts the physician's despair, helplessness, and horror that he registers during his break time while sitting on his car hood in the parking of his hospital:

I sat on the hood of the car

Watching the mirage on the tar

Thinking of patients lost so far

Who seem to be waiting not afar (pp. 1-4)

The speaker is terrorized by the death inside the hospital and by expecting higher mortality rates. $\mathrm{He}$ is in a state of despair and cannot see beyond the darkness of the black asphalt. Nyström (2021) describes a post-apocalyptic setting as a "place of death rather than rejuvenation" (pp.71-72). Instead of looking up towards the road as a source of hope, the doctor's gaze goes down to observe "tar," which probably foreshadows a gloomy future that brings across more doom and pain. Cohen and Pielak (2016) stress that post-apocalyptic narratives register a "transformation from present circumstances to some generally tragic future, exposing social fears that bring about tragic 
outcomes" (p. 243). Like many people in the Covid-19 context, the poet expresses his fear of losing loved ones and skepticism about the future. Through articulation and sharing of personal feelings and fear, the poet seeks solidarity and strength to face future horrors at work and in society during this calamity. Sollazzo (2017) illustrates that when we express our feelings in literature, we become more capable of facing them. Sollazzo (2017) further indicates that revealing our terrors aesthetically is an indicator of greater horrors. Hence, the poet fear signifies his realization that this demonized virus endangers everyone:

Nothing came to mind but fear

For those that I love who are near

Who know nothing of the virus's snare

Set so vast with none to spare (pp. 5-8)

The poet's expression of his distress reveals his feelings of helplessness and lack of knowledge and ability to destroy this deadly, swift, and malicious infection.

Besong's poem represents coronavirus as mysterious, vast, rapidly spreading, and undefeatable. The speaker describes it as an unknown massive enemy at a universal level, which makes it comparable to the apocalyptic spread of an uncontrollable fatal pandemic that threatens human survival. Readers witness the pain of losing patients at the hospital, the likelihood of losing loved ones, or even the fear of becoming infected and exposed to severe pain. Hence, the poem's setting is "not a place to kindle hope" (Nyström, 2021, 72). Additionally, Clasen (2019) highlights that post-apocalyptic literature causes its readers to "engage cognitively and emotionally" (p. 5), as is the case in this poem. A significant part of this engagement results from the real tragedy that, despite its horrendous nature, is probable and sometimes undefeatable. The poem divides people into three categories: the dead, the infected and awaiting death, and the horrified of becoming infected or losing loved ones. The epidemiologist sets a scene of uncontrollable, inevitable, and agonizing death that cannot be defeated. His description of the severe pain that the infected feel before they succumb to the deadly enemy adds macabre to the poem and escalates feelings of danger:

But then the cries of those in pain

Wallowing in the virus gains

Their noise enough to stop a train

And now I wish I was not trained (pp. 17-20)

Besong's description of coronavirus patients' "pain" amplifies the intensity of suffering rather than investigates the physical details of the illness, such as fever or suffocation. Further, the poem registers the poet's horror in reaction to encountering infected people. This fear makes the narrator's suffering, mental disturbance, and emotional pain the center of attention and sympathy. Hill (2018) draws attention to the fact that pain is "an important element" in post-apocalyptic literature and that it is a fundamental part "in the human experience" because it can "contribute to one's humanity" (p. 129). Despite his intensity of torture, Besong (2020) does not give up his vocation and resumes his quest to save the world from total annihilation.

Arab World English Journal for Translation \& Literary Studies 
The second category of poems this research explores is the poetry of resilience that depicts coronavirus context as a time of rebirth and restoration of human values, connectedness, and bonding with nature. Gill (2020) posted Love in the Time of Coronavirus on her Instagram account in March, and after that, the Indian/British poet recited her poem on YouTube in May. The poem borrows its flashy title from the Colombian Gabriel García Márquez's Love in the Time of Cholera (1985). As Márquez's $20^{\text {th }}$-century novel depicts the love between a man and a woman, the $21^{\text {st }}$ century-coronavirus poem demonstrates love among all humans, love of nature, and love of aesthetic culture as a source of peace and serenity during the time of Covid-19. The poem announces the superiority of feelings and love and the inferiority of materialism in its first line:

Today we stockpile empathy

We supply love and good energy

We sing to each other across buildings

We say 'I love you' through social distancing (pp. 1-4)

The first lines of the poem stress storing compassion and caring instead of collecting goods and food. Watkin (2020) stresses that "the post-apocalyptic genre can be used not merely to warn, look back and mourn, but also to generate new ideas and possibilities for humanity" (p. 11). The lines mark the significance of providing positive feelings and overcoming lockdown and isolation through spreading love. In so doing, the poem indicates that prevailing materialism in postmodern capitalist societies is the actual infectious virus. The poem further prescribes a treatment to overcome human contemporary moral follies by consulting ethics and compassion, which underlines Galofaro's (2021) view of coronavirus as "a sort of punishment for Western lifestyle" (p. 127). This perception connects Gill's poem to the themes of post-apocalyptic literature, where human survivors become aware of their abuse of each other and their decayed moral system. Nyström (2021) indicates that post-apocalyptic literature reverses the "traditional Western Enlightenment context" that usually develops from "barbarity to refinement" and from primitiveness to civilization on the material level (p. 66). This research debates that, on the moral level, the post-apocalyptic context displays improved human values and illustrates remorse for corruption committed before the catastrophe. By rectifying human behavior to provide a remedy, the poem indicates that corruption is the actual cause of the threatening apocalypse. In so doing, the text engages readers directly in actual life events. It allows them to "make use of formal literary techniques that invite readers to take the perspective of protagonists, that facilitate transportation into an imaginary world and sustain interest and possibly suspense, and that help us feel sympathy for fictional characters" and probably identify with them instead of only sympathizing with them (Clasen, 2019, p. 5).

The poem provides a positive perspective of lockdown. Instead of considering it a form of isolation and aloneness, it describes it as a means of revitalizing nostalgic activities, such as the actual writing of letters and reading of books:

Do you know that writing letters

to our friends is back in fashion?

And that we finally have time to read more books, whether historical or fiction (pp. 5-8) 
These lines signify that the poem questions technological advancement and probably reveals skepticism about electronic forms of human communication. Heffernan (2015) emphasizes that "industrial and academic scientists - from chemists to physicians to engineers -were recruited by the state to design new technologies: submarines, machine guns, aerial bombing and chemical weapons made this war 'more bloody' and 'more destructive" (p. 68). Thus, the author abandons features of the postmodern world and seeks asylum in nature and love. For example, the text indicates a retreat of email writing and e-book reading and links the poem to a significant genre ideology: human adaptation to available modes of life after the fall of the catastrophe. These modes can signal a departure from social or scientific advancement. Another sign of going back in time is the choice of historical books. Heffernan (2015) highlights that "Albert Einstein remarked that 'anyone who thinks science is trying to make human life easier or more pleasant is utterly mistaken"' (p. 69). Therefore, the poem underlines the necessity to learn from the past about living peacefully on the planet.

Calling for appreciation of nature, preservation of its resources, and protecting it against different forms of pollution are essential themes in Gill's poem that links it to post-apocalyptic literature:

My cousin told me she hadn't seen

such a blue sky in her city before

My uncle went on his walk in the woods

He heard a bird sing since the first time he went to war (pp. 9-12)

These lines' portrayal of the recovery of nature where a sky gains its lost blueness. Other nonhuman beings also appear and practice their long-abandoned activities, such as the singing of the bird. The third stanza links humans' violence - war - to the disappearance of the bird's singing. In so doing, the poem suggests that humankind's irrational practices are the reasons behind the disappearance of nature's beauty. It also indicates that people's misbehavior caused animals' deprivation of practicing activities in their habitats, which is another central theme of postapocalyptic literature. Thus, the text implies nostalgic feelings about the pre-war era when humans exploited nature less. Sollazzo (2017) underlines that the survivors in post-apocalyptic literature are always preoccupied with the past and refer to it all the time to cope with pain and loss (473474). In its last three stanzas, the poem displays resilience and hope in four ways. Firstly, it invites readers to conquer the present distress during the Covid-19 context through adapting to the limitations of lockdown and social distancing. Secondly, the poem encourages the preservation of nature and links it to human safety. Thirdly, the poem requests humans to bond with each other and share feelings of love and care to overcome loneliness and fear. Hence, the text is a call to find asylum in verse, and literature can heal the pain that follows an apocalyptic catastrophe.

The third poem that this research tackles is Mitchell's (2020) The Doctor and Apocalypse. It was published in The New York Times, and it describes the battle that an emergency physician at Boston Medical Centre fights. However, the poem is inconsistent in its representation of the Covid19 despite the title's insinuation of the end of the world and the death of its inhabitants. Mitchell (2020) starts her poem with a declaration of the end of the world: "This is the apocalypse" (p. 1). 
Conversely, the following line describes the blooming of a daffodil as it nourishes on a sunny clear day:

"A daffodil has poked its head up / from the dirt and opened" (pp. 2-3). The poem provides a postapocalyptic scene. As the title reveals, it draws attention to the reconstruction of life and nature after the destruction of the world and the death of its occupants. Moon (2014) reveals that "the age-old power relation of 'nature under the control of civilization' is reversed into that of "civilization under the control of nature" (p. 6). Hence, there is a resurrection of nature in the aftermath of the massive destruction. This revival is the source of hope for humanity in the universe. The poem provides two spatial settings: the first is the hospital emergency room where the doctor stands as a fearful and anxious warrior who fights the mystic and invisible fatal tiny enemy, coronavirus:

My stomach twists and fingers shake

as I prepare to work the battleground

the place I've always loved and felt at home

is now a field of droplets sprayed across a room (pp. 11-14)

The second setting is the outer space - nature - where people roam peacefully and participate in different kinds of activities that do not relate or intersect with the other setting. In contradiction with the suffocating emergency room full of death, smells of medications, and disinfectants, nature is full of sunshine and celebrates the arrival of spring. Nyström (2021) highlights that "Western mythologies of pastoral gardens" are deeply rooted in literary and cultural writings (p. 1). The poem additionally provides plenty of space for non-human beings, the colorful flowers in the "backyard" and the dogs that walk joyfully with people:

as spring begins again

and brightly colored flowers

deploy in my backyard

the neighbors walk their dogs

and march along the quiet streets (pp. 20-24)

By using the term "again," the poet engages a past activity in the post-apocalyptic present. As previously stated, this leads to the past vs. present dichotomy. Additionally, it indicates that the past reemerges into the future. Moon (2014) contends that in post-apocalyptic literature, temporality is primarily "in transition" (p. 5). Amid the two contradictory worlds and the conflicting past and present, the emergency doctor stands as a warrior in her own hospital/battlefield. However, instead of wearing a fighter's shield, she wears her medical "gown" to confront a different sly, and deceitful enemy.

I stretch my purple gloves on steady hands

I tie my yellow gown behind my back

my hair inside a blue bouffant

my mouth and nose and eyes are 
still and calm inside their waiting shields.

This is the apocalypse. (pp. 25-30)

The last few lines illustrate that Mitchell does not become a victim of despair. She does not resent her job as a frontline doctor, either. Like Gill, she believes in the human capacity to overcome the apocalypse by bonding with others and restoring nature. These features associate the two poems with post-apocalyptic elements, such as the end of life and constructing a new world (Moon, 2014, pp. 111). Although Mitchell (2020) provides two contradictory depictions of the world under the effect of Covid-19, she does not give in to death, nor does she become a victim of despair as Besong (2020) does. Conversely, she helps in the saving process and, simultaneously, watches the emerge of the new world.

\title{
Conclusion
}

To conclude, this paper argues that literature produced during the Covid-19 context features post-apocalyptic conventions by depicting tragic situations, loss, death, and emotional chaos. The research debates that examined poems show contradiction between isolation and connectedness and between resilience and despair. The scholar analyzes the ideology of survival in the selected texts as a central theme in the genre. This study suggests that readers of coronavirus poetry relate to the narrators' experiences, which enhances the sense of realism in these texts and, paradoxically, makes the poems a combination of imagination and realism. The paper also suggests that depicting the effects of the pandemic in poetry increases transnational and transcultural bonding, which resists social distancing and physical isolation.

Literature has always been a means of expression through which writers share their pains, fear, sufferings, and other forms of psychological distress. In her On Being Ill, Woolf (1993) clarifies that literature is commonly concerned "with the mind" and all illustrations of emotional and psychological disturbances (p. 32). Woolf (1993) draws attention to the fact that very little attention is devoted to depicting physical aches and sufferings. She gives examples of Shakespearean tragic heroes, such as prince Hamlet and King Lear, whose body pain is rarely mentioned or examined. Even though there is a slight depiction of some descriptions of a "corner of the hospital," Woolf (1993) emphasizes that there is very little attention or sympathy given to physical suffering (p. 35). In response to this, the researcher reveals that healthcare staff and doctors write many texts about the emotional pain of loss or fear of contamination. However, very few, if any, depict bodily pains of patients, symptoms of contamination, severe fever, or any other sign of illness that accompany coronavirus infection. Therefore, the author calls writers and poets to record this historical period that registers how it is like being a coronavirus victim. The scholar further calls academics to explore texts to identify the presence of literature that demonstrates bodily anguish.

\begin{abstract}
Abou the Author:
Dr. Nesreen Al-Harby is an Assistant Professor of English literature in the Department of European Languages and Literature at King Abdulaziz University, Saudi Arabia. She received her Ph.D. in Literary and Cultural Studies and Genre Theory from the University of Leicester, UK. Her research interests include postmodern representations of women in literature and the
\end{abstract}


AWEJ for Translation \& Literary Studies Volume, 5 Number 3. August 2021

Coronavirus Apocalypse: A Representation of Despair and Resilience

Al-Harby

cybersphere, Genre Theory and effects of employing genre conventions and tropes, postcolonial and neo-Orientalist writings, and autobiographical writings. ORCID ID: https://orcid.org/00000002-4619-8863

\section{References}

Besong, M. (2020). My Struggle with COVID-19. TEPHINET. https://www.tephinet.org/poemfrom-an-feltp-graduate-my-struggle-with-covid-19.

Campo, R., \& New, E. (2021). The Art of Losing-Three Poems for the COVID-19 Pandemic. JAMA, 325(1), 12-13.

Carroll, J. (2006). The Human Revolution and the Adaptive Function of Literature. Philosophy and Literature, 30(1), 33-49. http://doi:10.1353/phl.2006.0005

Chriscaden, K., (2020). Impact of COVID-19 on People's Livelihoods, their Health and our Food Systems. World Health Organization. https://www.who.int/news/item/13-10-2020impact-of-covid-19-on-people's-livelihoods-their-health-and-our-food-systems

Clasen, M. (2019). Imagining the End of the World: A Biocultural Analysis of Post-Apocalyptic Fiction. In D. Vanderbeke \& B. Cooke (Eds.), Evolution and Popular Narrative (pp. 6482). Brill Rodopi.

Cohen, A., \& Pielak, C. (2016). Archiving the Apocalypse. The Midwest Quarterly, 57(3), 241261.

Dillon, S. (2007). Imagining Apocalypse: Maggie Gee's" The Flood”. Contemporary Literature, 48(3), 374-397.

Epstude, K., \& Peetz, J. (2012). Mental Time Travel: A Conceptual Overview of Social Psychological Perspectives on a Fundamental Human Capacity. European Journal of Social Psychology, 42(3), 269-275. https://doi.org/10.1002/ejsp.1867

Galofaro, F. (2021). Apocalyptic Features of Political Discourses about the Pandemic. Revista Acta Semiotica Forum, (1). https://doi.10.23925/2763-700X.2021n1.54167

Gill, N. [@nikita_gill]. (2020, March 17).Love in the Time of Coronavirus. Instagram. https://www.instagram.com/p/B918TfbJ_dO/

González-Padilla, D. A., \& Tortolero-Blanco, L. (2020). Social Media Influence in the COVID19 Pandemic. International braz j urol, 46(1), 120-124. https://www.scielo.br/j/ibju/a/nV6DpnQf7GWYrd94ZcHQBWz/?format=html\&lang=en

Heffernan, T. (2015). The Post-Apocalyptic Imaginary: Science, Fiction, and the Death Drive. English Studies in Africa, 58(2), 66-79. https://doi.10.1080/00138398.2015.1083198

Heller, J. (2015). Does Post-Apocalyptic Literature Have A (Non-Dystopian) Future. Book News and Features Review, National Public Radio. https://doi.text.npr.org/402852849

Hicks, H. (2016). The Post-Apocalyptic Novel in the Twenty-First Century: Modernity Beyond Salvage. Springer.

Hill, T. (2018). Post-Apocalyptic Literature: Humanity’s Survival Tool. The National Conference on Undergraduate Research. http://libjournals.unca.edu/ncur/wpcontent/uploads/2021/03/2554-Hill-Tessa-FINAL.pdf Houfková, K. (2019). The Warning Function of Post-Apocalyptic Science Fiction.” Messages, Sages and Ages, 6(1), 59-65.

Arab World English Journal for Translation \& Literary Studies 
Ketterer, D. (1971). New Worlds for Old: The Apocalyptic Imagination, Science Fiction, and American Literature. Mosaic, 5(1), 37-57.

Lepore, J. (2017). A Golden Age for Dystopian Fiction: What to Make of Our New Literature of Radical Pessimism. The New Yorker, 5(12). www.newyorker.com/magazine/2017/06/05/a-golden-age-for-dystopian-fiction.

Manis, K. (2018). Neoliberal Anxiety and the Post Apocalypse in US Comic Books: An Analysis of the Last Man and the Private Eye. The Journal of Popular Culture, 51(5), 1234-1255.

Mitchell, E. (2020). The Doctor and Apocalypse. The New York Times. https://www.nytimes.com/2020/03/24/us/coronavirus-doctor-poetry-boston.html

Moon, H. (2014). The Post-Apocalyptic Turn: A study of Contemporary Apocalyptic and PostApocalyptic Narrative. The University of Wisconsin-Milwaukee.

Morton, T. (2013). Hyperobjects: Philosophy and Ecology after the End of the World. University of Minnesota Press.

Natural History Museum. (2020). Nature: Liberated by Lockdown? Available at https://www.nhm.ac.uk/discover/nature-liberated-by-lockdown.html

Nicewaner, P. (2020). Nostalgia during Times of Crisis: Why your Childhood. The Standard. http://www.the-standard.org/opinion/nicewaner-nostalgia-during-times-of-crisis-whyyour-childhood-teddy-bear-is-more-important-than/article_373eae8e-f9fd-11ea-95abb367b5547a0d.html.

Nyström, A. (2021). Places of Rest in Worlds of Ruin: Havens in Post-Apocalyptic Fiction (Doctoral dissertation). Karlstads universitet, Sweden.

Oventile, R. S. (2002). Post-Apocalyptic Representations as Symptoms of Trauma. The Review of Communication, 2(1), 103-108. Available at http://www.natcom.org/roc/oneone/January2002/OventileonBerger.htm

Peters, M. A. (2021). The Plague: Human resilience and the collective response to catastrophe. Educational Philosophy and Theory 53(8), 755-759. 10.1080/00131857.2020.1745921

Rodríguez-Rey, R., Garrido-Hernansaiz, H., \& Collado, S. (2020). Psychological Impact and Associated Factors during the Initial Stage of the Coronavirus (COVID-19) Pandemic among the General Population in Spain. Frontiers in Psychology, 11(6), 1-23. https://doi.org/10.3389/fpsyg.2020.04.005

Shereen, M. A., Khan, S., Kazmi, A., Bashir, N., \& Siddique, R. (2020). COVID-19 Infection: Origin, Transmission, and Characteristics of Human Coronaviruses. Journal of Advanced Research, 24, 91-98. https://doi.org/10.1016/j.jare.2020.03.005

Snyder, K. V. (2011). "Time to Go": The Post-Apocalyptic and the Post-Traumatic in Margaret Atwood's "Oryx and Crake." Studies in the Novel, 43(4), 470-489. http://www.jstor.org/stable/41319888

Sollazzo, E. (2017). "The Dead City": Corporate Anxiety and the Post-Apocalyptic Vision in Colson Whitehead's Zone One. Law \& Literature, 29(3), 457-483. https://doi.org/10.1080/1535685X.2017.1327696

Stifjell, C. A. (2018). Life in the Ruins: Post-Apocalyptic Narratives of Survival, (Unpublished Master's Thesis). Norwegian University of Science and Technology, Norway.

Tsing, A. L., Bubandt, N., Gan, E., \& Swanson, H. A. (Eds.). (2017). Arts of Living on a Damaged Planet: Ghosts and Monsters of the Anthropocene. University of Minnesota Press. 
AWEJ for Translation \& Literary Studies Volume, 5 Number 3. August 2021 Coronavirus Apocalypse: A Representation of Despair and Resilience

Watkins, S. (2020). Contemporary Women's Post-Apocalyptic Fiction. Palgrave Macmillan.

Woolf, V. (1993). On Being Ill. Sage. 6(2), 199-201. https://doi.org/10.1111/j.17416248.1993.00199.x 